ECONOMICS

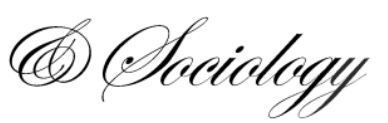

Muhamad, S, Kusairi, S., \& Zamri, N. (2021). Savings behaviour of bottom income group: Is there any role for financial efficacy and risk preference?. Economics and Sociology, 14(2), 56-70. doi:10.14254/2071-789X.2021/14-2/3

\title{
SAVINGS BEHAVIOUR OF BOTTOM INCOME GROUP: IS THERE ANY ROLE FOR FINANCIAL EFFICACY AND RISK PREFERENCE?
}

\begin{abstract}
Suriyani Muhamad
Universiti Malaysia Terengganu

E-mail:suriyani md@umt.edu.my

ORCID 0000-0002-9928-8993

\section{Suhal Kusairi \\ Universiti Malaysia Terengganu \\ E-mail:subal@umt.edu.my \\ ORCID 0000-0002-9156-6741 \\ * Corresponding Author}

\section{Nadia Zamri \\ Universiti Malaysia Terengganu \\ E-mail:nadiaa.zamrii@gmail.com \\ ORCID 0000-0002-5100-2386}

Received: June, 2020

1st Revision: March, 2021

Accepted: May, 2021

DOI: $10.14254 / 2071$ -

789X.2021/14-2/3

JEL Classification: G40, G41, G51, G32, D14, R51

\begin{abstract}
An immense concern of governments globalwide today is financial inclusion as one of the Sustainable Development Goals (SDGs). Governments arrive at many solutions by addressing the policies to improve financial achievement, mainly through financial education programmes and specifically personal finance. Yet, financial management has such a broad scope and is not limited to just knowledge and financial literacy. Individuals are born with different confidence levels and non-identical financial abilities. This study investigates financial self-efficacy by applying psychometric instruments, risk preference and demography characteristics towards saving decision behaviour. The sample in the survey consisted of 479 respondents in Peninsular Malaysia that then became subject to structural equation modelling. The results show that financial self-efficacy is one of the critical factors that explain individual saving decision behaviour. Also, risk preference, gender and area (rural or urban) determine the saving decision behaviour. This paper also implicates that there might be a gap between the rural and urban levels of financial efficacy that needs government's action to narrow it.
\end{abstract}

Keywords: behavioural finance, financial efficacy, saving behaviour, risk preference, demographic factors.

\section{Introduction}

The increasing prices for goods and services affect individuals, especially in the lowincome groups since they are forced to spend most of their income on goods to meet their basic needs. Food inflation in particular has risen faster than inflation overall (Ramiah et al., 2015). For example, food costs in Malaysia increased by $4.40 \%$ in October 2017 as compared to the same month in the previous year. Meanwhile, food inflation in Malaysia averaged $3.73 \%$ in the period of 2011 to 2017, reaching the peak of 5.67\% in October of 2011 and recording the lowest level of $1.97 \%$ in December 2012 (EPU, 2017). Since this consumption problem is directly related to higher costs of living overall, savings among individuals is also affected. The lowincome group has less chances to isolate part of income as savings. Malaysia has one of the lowest savings rates globally, at $1.4 \%$ of the adjusted disposable income in 2013. Malaysia's 
household savings rate was averaging at 1.6\% between 2006 and 2013 (Bank Negara Malaysia, 2016). This becomes the most pressing issue among consumers, especially in the low-income group, where the failure to make any savings is apparent. One of every three Malaysian does not have a savings account while most of them have not saved enough to ensure living for five years after leaving employment (EPF, 2015).

Low-income earners tend to have especially little chances to save money for a significant investment or future consumption. Thus, careful financial planning regarding savings is one of the most important means for an even consumption activity in the future. Financial decisions are crucial for the individuals' stability in the face of financial challenges, whether expected or unexpected. A survey by EPF (2015) proved that $76 \%$ of the Malaysians have difficulties raising RM 1,000 for emergency cash. Surprisingly, $68 \%$ of the EPF members aged 54 have less than the target saving that people should have, which is RM 50,000. This problem raises the government's attention since there is an obvious need to find a solution and try to achieve higher levels of savings, especially among households, by pinpointing the aspects that might be the key contributors to that.

Academia strongly argues that high savings are related to wealth as measured by GDP per capita. Some analysts believe they are also related to the exchange rate, financial intermediation, capital market development, national traditions, demographic structure, and the social security system. Based on the Youth Research Institute's findings in Malaysia (2011), the factors that influence the spending patterns are for 38.2\% income, $26.2 \%$ own needs, $10.9 \%$ own preferences, $23.1 \%$ household, $1.1 \%$ friends, and $0.5 \%$ other. It is clear that within the pattern of spending, more than a half is determined by the factors of households and individuals themselves. Since half of all spending is dominated by self, it is crucial to view this as a chance that might be used in restructuring of consumption to solve the problem regarding the lack of savings among individuals.

The government had already taken efforts to raise the savings rate. Among these are: 1) policies to improve financial literacy that might have a significant impact on saving; 2) controlling for some other financial factors such as interest rates. Improving financial literacy, mainly through financial education programmes and specifically personal finance, could not be the only rescue nowadays since financial management has such a broad scope and is not limited to just knowledge and financial literacy. People may learn financial literacy, but this is not a guarantee they will necessarily implement it in the real world. Besides, most researchers are unable to seek practical ways of improving financial literacy, and there is a lack of evidence to prove that those with more financial knowledge are actually making better decisions (Willis, 2008).

The existing studies focused on how financial literacy, income, and other mentioned factors affect savings among individuals without discovering in-depth about the self-ability born inside economic agents. Individuals are born with different confidence levels in themself and also with non-identical financial abilities. In line with this ability issue, Bandura (1977) presented a self-efficacy scale that might picture internal trust towards oneself as the definition of what kind of words could explain person's belief about their capability to complete any tasks to gain success. So the question is: what is the linkage between financial self-efficacy, risk preference and demographic characteristics with individual saving behaviour within a low-income group?

When it comes to application of self-efficacy in economic decisions and/or financial decision behaviour, it could be argued that an individual who has a greater sense of selfassuredness in their expenditure and financial management capacities is more likely to approach economic and financial difficulties they encounter as the challenges to be faced rather than as threats to be avoided (Bandura, 1994; Farrel et al., 2015). Such a positive attitude is likely to result in achievement and, consequently, more favourable individual financial outcomes. 
Therefore, this paper aims to seek evidence on the efficacy that would affect saving effectiveness and thus could further implement this theory to create a new policy related to low-income households in Malaysia. The main contribution of this research is that it adds to the literature on the bottom income groups, namely, their savings decisions related to the roles of individual financial efficacy, risks preferences, and demographic characteristics.

The rest of the article is organised as follows: 1) Literature review will be focused on the behavioural finance theory and the previously obtained empirical findings. 2) The methodological part describes data and irs sources, the operationalisation of variables, sampling, specification model, and structural equation modelling (SEM). 3) Results and discussion go next, and lastly. 4) Conclusions and recommendations are provided.

\section{Literature review}

The study of self-efficacy is a theory in the field of economic psychology that researchers have frequently studied over the past decade (Lown, 2015; Callender \& Schofield, 2016). Economic psychology, which is not a new field by any means, is just one way of interpreting other factors that impact many economic indicators, including saving. This concept could be particularly useful for understanding economic behaviour. In other words, economic behaviour could be represented by consumers' behaviours that involve financial decisions and the determinants and consequences of a particular economic decision. One kind of dominant element that exists in economic psychology is self-efficacy (Farrell, 2016). Self-efficacy represents an optimistic sense of personal competence that seems to be a pervasive phenomenon that accounts for human beings' motivation and accomplishments (Scholz, 2006). This research details the most common activities that are considered necessary by humans, particularly those that make up households that are successful with their saving, by taking into account economic agents' behaviour.

By discovering these abilities, a low-income earner will possess a powerful tool regarding their own belief in economic decisions, resulting in steady behaviour when planning their saving. We realised that low-income earners did saving in some form, sporadically and in small amounts. Many ways that consumers practised high self-efficacy could be directly observed and implanted into those who lacked belief. Influenced by the initial development of the self-efficacy concept by Forbes and Kara (2010), this research uses the term to refer to one's belief in their capability to achieve saving.

According to Bandura and Wood (1989) and Marlatt and Donovan (2005), we can make the best prediction towards how successful a person will be at making decisions, including those related to saving, by using the self-efficacy indicator. The higher one's self-efficacy, the higher their tendency to make a better saving decision because they believe that they can adequately perform that kind of activity. One early strand of research related to financial efficacy is by Asebedo et al. (2019), whose authors discussed how financial self-efficacy beliefs, particularly those related to saving behaviours, might be fostered. Subsequent research has also proved that self-efficacy is one of the most influential factors in human life, with an ability to combat depression (Maciejewski et al., 2000), lessen stress and improve quality of life (Prati et al., 2009), and increase dietary knowledge and positive behaviour (Rimal \& Moon, 2009). Similarly, financial efficacy could signal how good a person is doing in their saving, or what is generally referred to as an investment for one's entire life (Forbes \& Kara, 2010), wealth accumulation and portfolio choice (Chatterjee et al., 2011). Interestingly, Rothwell et al. (2016) found that financial self-efficacy was an effective mediator in the relationship between objective financial knowledge and postsecondary-education saving. 
The self-efficacy concept has also been applied as an independent variable in a standard model of economic behaviour to evaluate its significance in predicting investigated behavioural outcomes. There are previous studies that have assessed the explanatory power of the related concepts of 'economic self-efficacy' (Graboski et al., 2001), 'investment self-efficacy' (Forbes \& Kara 2010), 'entrepreneurial self-efficacy' (Kickul et al., 2008), and women's personal finance behaviours (Farrell, 2015). Generally, the results find that financial self-efficacy could positively explain the more favourable individual economic or financial outcomes. In this case, a phenomenon is given as a savings decision, and its self-efficacy is directed towards an individual's saving. The level of self-efficacy generally depends on one's needs, ability, capability, and self-control from a psychological perspective, as well as one ability to mark anomalies that could explain how this kind of activity could be carried out. The inner belief of an individual will guide how vital they believe personal saving to be, which will then give the incentive to do it wisely. Because it is believed that competent functioning requires both the skills and a self-belief to succeed in financial management tasks, the ability to hold a firmer belief will lead to greater success in saving. Self-efficacy is displayed by how successful the individuals tend to manage their financial matters in relation to their saving decisions. According to CobbClark et al. (2014), a person with an internal reference saves more in terms of the particular level and percentage of their permanent incomes.

\section{Methodological approach}

\subsection{Research model}

This research integrates a psychological construct (financial self-efficacy) to understand economic agents' behaviour, focusing on their saving decisions and psychometric application. The financial self-efficacy, as well as demographic factors and risk preference, all have effects on saving decision.

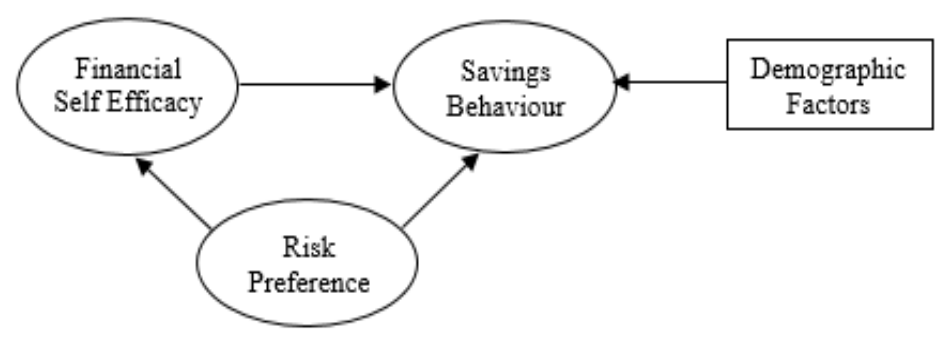

Figure 1. Conceptual framework of the relationship of financial self-efficacy, risk preference, and savings behaviour

Figure 1 explains the conceptual framework for the bottom lower-income household's financial self-efficacy, which contains three variables: saving, financial self-efficacy, and risk preference. The oval shape of the framework represents latent or unobserved variables. An unobserved variable is a variable that cannot directly be seen or directly measured and could be understood as either a dependent or independent variable. As mentioned in the introduction and literature review, however, this research treats saving as a dependent variable and the others as independent variables. The variable represented in the rectangle is the demographic factor. This variable will stand as the observable variable, or measured variable. The variables that contribute to these main variables are gender (male or female) and area (urban or rural). 
As argued by Callander and Schofield (2016), a low-income standard of living will eventually decrease through financial self-efficacy. In this paper, the authors state that poverty might negatively influence people's self-efficacy because they might be expected to make a lifechanging decision to more readily improve their living standards and thus avoid or move out from poverty. Practicing saving habits is one of the most effective ways to end poverty; the higher one's self-efficacy, the higher their tendency to save because they believe that they can perform such activity habitually and eventually save significant amounts of money, which could be one of the shields or buffers when unpredictable occasions occur. As mentioned earlier, saving habits are the most effective solutions to end poverty. As Bandura (1977) explains, self-efficacy is about a person's beliefs regarding their ability to complete tasks with success.

Good financial behaviour is not achievable until we believe that it is. Perceived financial self-efficacy and financial risk tolerance can predict participants' intentions to save and create a financial buffer (Magendans et al., 2016). Higher financial self-efficacy, older age, and middle incomes are all associated with a higher likelihood of savings (Lown, 2011). The study by Farrell (2015) reveals that the higher a woman's financial self-efficacy, the greater their self-assuredness in their financial management capacities, which results in greater investments and the purchasing of more savings products. Farrell (2015) also found that these women are less likely to own debtrelated products.

Tokunaga (1993) concludes that psychological variables such as financial self-efficacy significantly increase one's ability to distinguish between prudent and unhealthy credit users. According to Marlatt (985), a higher financial self-efficacy will be the best predictor of a positive saving attitude, which suggests that it could potentially signal how good a person is doing their savings, or what is generally considered to be an investment towards their entire life (Forbes \& Kara, 2010). In addition, Asebedo and Seay (2018) reveal that financial self-efficacy beliefs are positively related to saving behaviours. Trent and South (1992) state that personal attitudes might be influential factors towards interpreting behaviours of an entire family. In line with this, Munichan (1985) writes that individuals contribute considerably to the perception of a family as an organised system.

This study also analyses the relationship between saving and risk preference. Risk preference is the tendency to choose a risky or less risky option. Generally, economists and financial professionals apply the concept of risk preference to investment and financial decisions. In our research, it applies to one's personal preference for risk. An individual characteristic measures one's a personal preference for risk and whether or not they are willing to take a financial risk if they have spare cash for a saving activity. Lian and Ma (2018) prove that households might set the reference level of the interest rate. When the rate falls below the reference level, people experience discomfort, which encourages them to make a better savings plan or increase savings. To put it simply, there is an inverse relationship between both of these variables, meaning that a lower risk preference corresponds to a higher saving. Supported by Brown et al. (2008), risk preference is a critical determinant of unsecured debt acquired at the household level, with risk aversion serving to reduce the level of unsecured debt accumulated by households. People directly reduce their debt when they have a backup plan as saving.

Various kinds of studies have also researched demographics to better understand how this factor influences the savings behaviour. Demographics are respondents' characteristics related to social and demographic factors such as household income, gender, ethnicity, age, education, location (rural or urban), dependency ratio, and marriage status. To this end, Hussain et al. (2016) studied the effects of select demographic and socioeconomic variables on labour force participation. Hopkins (2014) also studied how gender could contribute to borrowing expansion, proving that women expand their expenses to a greater degree than men. There is a significant correlation between gender and saving (Fisher, 2010). According to Hufner and Koske (2010), 
saving is influenced by one's current real income, several demographic factors, and real return rate.

A comprehensive investigation will be conducted through a Structural Equation Model (SEM). B40 groups rarely make a big purchasing and savings. Some of these differences data are easily noticeable, whereas others are a little more difficult to observe. The next step is to determine the research constructs and elucidate how these operationalise into the scale items.

\subsection{Structural equation model}

The first latent variable, saving (SAV), is modelled as i-indicators (six questions) in the same group and can be written as follows:

$$
Q_{i}=\sum_{i=1}^{n} \lambda_{i} S A V_{i}+\delta_{i}
$$

The second latent variable, financial self-efficacy (SE), is modelled as i-indicators (ten) questions) and can be written as follows:

$$
Q_{i}=\sum_{i=1}^{n} \lambda_{i} S E_{i}+\delta_{i}
$$

The third latent variable, risk preference (RISKP), is modelled as i-indicators (three questions) and can be written as follows:

$$
Q_{i}=\sum_{i=1}^{n} \lambda_{i} R I S K P_{i}+\delta_{i}
$$

The formula for an endogenous variable is

$$
S A V_{i}=\Lambda_{11} S E_{i}+\Lambda_{31} R I S K P_{i}+\zeta_{i}
$$

where SAV represents saving itself, SE represents self-efficacy, and RISKP represents risk preference.

\subsection{Operationalisation of variables}

Table 1 presents the research variables, their definitions, and indicators that make up the basis of questionnaire development. There are ten questions related to financial self-efficacy, as adopted from Lown (2011, 2015). Moreover, we developed three questions about risk preferences and six questions about saving behaviours based on indicators of variables.

Table 1. Operationalisation of Variables

\begin{tabular}{lll}
\hline \multicolumn{1}{c}{ Variables } & \multicolumn{1}{c}{ Definition } & \multicolumn{1}{c}{ Indicator/Item } \\
\hline $\begin{array}{l}\text { Financial } \\
\text { Self-Efficacy }\end{array}$ & $\begin{array}{l}\text { It relates to one's ability to cope with a } \\
\text { situation (Farrell, 2015); self-beliefs set } \\
\text { (Schwarzer \& Jerusalem, 1995). }\end{array}$ & $\begin{array}{l}\text { Measures how far a person believes in their } \\
\text { capability in deciding financial matters, } \\
\text { including spending and saving, which can be } \\
\text { denoted as the main activities of daily life. A } \\
\text { high financial self-efficacy means that one } \\
\text { has a high self-belief. }\end{array}$ \\
\hline Risk & $\begin{array}{ll}\text { It could be divided into various stages } \\
\text { Preference } \\
\text { that make up part of the risk (PEP- }\end{array}$ & $\begin{array}{l}\text { Light risk or shocks that are faced by the } \\
\text { household every day (e.g., immediate need }\end{array}$ \\
& $\begin{array}{l}\text { CBMS Network Coordinating, 2011). } \\
\text { The underlying risk that households } \\
\text { might face in their daily lives is }\end{array}$ & for money to buy cooking gas for food). \\
unpredictable and light (Campbell, & $\begin{array}{l}\text { 2) Idiosyncratic risk } \\
\text { It usually affects the assets that households } \\
\text { have (e.g., car maintenance, house repairs, or }\end{array}$ \\
& $\begin{array}{l}\text { 2006). } \\
\text { It mostly affects assets that one or more } \\
\text { companies have. Risk also affects }\end{array}$ & \\
\hline
\end{tabular}


households, communities, regions, or even entire countries (PEP-CBMS Network Coordinating, 2011).

Savings It could be divided into two categories: Behaviour long-term saving and short-term saving. The former represents gold, while the latter pertains to monthly saving as a fixed deposit (Bosworth et al., 1991).
3) Covariant risk

A huge risk that might cause loss, affecting the self, family, and even the greater economy (e.g., unemployment and disaster).

There are short- and long-term saving types. Long-term saving represents gold, certificate saving premium, and ASB, while short-term saving represents fixed and current deposits.

Note: List of questionnaires (See Appendices A-C).

\subsection{Sampling and data collection technique}

This study adopted a survey and grounded research approach. The unit of analysis in this research is an individual from the bottom lower-income of households' group B40 households, which includes Malay, Chinese, and Indian ethnic families who live in either the urban and rural areas of Peninsula Malaysia. In particular, there are three urban areas and three rural areas from the states of Pahang, Johor, and Selangor.

Cluster proportional and systematic random sampling are the techniques used to close and present the population's character. To get strong and valid results for characteristics of the population, the minimum sample is determined by the cluster comparative systematic random sampling method. It is then distributed based on proportional allocation. The population is clustered based on states and urban areas. Significance level, standard error, the total population of each cluster, and the bound of error are considered. The research sample contained approximately 479 respondents from B40 households and the study was conducted in the second semester of 2017.

Data collection techniques include questionnaires, observations, and interview guidance. The questionnaire is given to all selected respondents from B40 households. Closed questions are used in this questionnaire and the options are given using the Liker scale model. The questionnaires are constructed based on a firm definition, determinant of dimension, and how to measure every variable. It is a critical step of survey research to ensure that the questionnaire items are related to the central issues being studied.

\section{Results and discussion}

The result discussion will begin with a descriptive analysis of the study's main variables, followed by an analysis of financial self-efficacy, demographic characteristics, and risk preference towards saving decision behaviours.

\subsection{Descriptive statistics analysis of B40 house}

Descriptive statistics will analyse the data's characteristics and patterns, which consists of the respondents' research area, gender, race, and education. Table 2 indicates the distribution of respondents from B40 households in a selected area of Peninsular Malaysia. This investigation is dominated by individuals who live in an urban area (368 respondents, $76.80 \%$ ), compared to those in a rural area (111 respondents, $23.2 \%$ ). In regard to gender, women made up $64.5 \%$ of the study (307). This is an interesting point that most females take care of the household and 
make decisions regarding the family matters. On another hand, there were 172 male respondents, making up $35.5 \%$ of the total sample.

Table 2. Distribution of respondents

\begin{tabular}{llccc}
\hline & Category & Frequency & Percentage $(\%)$ & Cumulative \\
\hline Area & Rural & 111 & 23.20 & 76.80 \\
& Urban & 368 & 76.80 & 100.00 \\
\hline Gender & Male & 172 & 35.50 & 35.50 \\
& Female & 307 & 64.50 & 100.00 \\
\hline \multirow{2}{*}{ Ethnicity } & Malay & 392 & 81.94 & 81.94 \\
& Chinese & 29 & 6.05 & 87.99 \\
& Indian & 49 & 10.23 & 98.22 \\
& Other & 9 & 1.88 & 100.00 \\
\hline Highest Level of & Never attended & 6 & 1.30 & 1.30 \\
Education & Primary & 40 & 8.40 & 9.60 \\
& Secondary & 315 & 65.80 & 75.40 \\
& Tertiary & 118 & 24.60 & 100.00
\end{tabular}

Sources: Fieldworks Data Analysis, 2018.

There are various ethnicities in Malaysia. However, Malays make up a large percentage, with 392 respondents or $81.94 \%$. Indian is the next most common: 49 respondents or $10.23 \%$. Chinese make up only $6.06 \%$ of the sample with 29 respondents, and 9 respondents $(1.88 \%)$ have a different ethnicity. In terms of the educational background of B40 households, 6 of them never attended school (1.3\%), 40 respondents attended primary school $(8.4 \%), 315$ received an education up to secondary school (65.8\%), making up the majority of respondents, and 118 respondents received a tertiary education at the college or university level $(24.6 \%)$.

\subsection{Reliability and Validity of Test Analysis}

Table 3 depicts the results of the item analysis that was developed based on the sharp definition of each construct. If the factors (dimension) appear to lack validity and reliability, it could mean that the item should be excluded in the causal model. For instance, item SE1's factor loading is lower than $0.5(0.480)$, so we excluded it. This paper adapted two measurements that can be useful for establishing validity and reliability: Composite Reliability (CR) and Average Variance Extracted (AVE).

All items denote a value higher than 0.5 for AVE and higher than 0.6 for CR. This value is supported by Fornell and Larcker (1981) who state that if the AVE is less than 0.5, but the composite reliability is higher than 0.6 , the convergent validity of the construct is still adequate. The AVE square root for the construct could be represented by the diagonal, while the remaining value represents the correlation between the construct in the row and column. We can consider that discriminant validity is achieved when the diagonal value is higher than the value in the row and its column. 
Table 3. Average Variance Extracted (AVE) and Composite Reliability (CR)

\begin{tabular}{lcccc}
\hline \multicolumn{1}{c}{ Construct } & Item/Sub Construct & Factor Loading & AVE & CR \\
\hline Financial & SE2 & 0.782 & 0.622 & 0.942 \\
\cline { 2 - 5 } Self-Efficacy & SE3 & 0.838 & & \\
\cline { 2 - 5 } & SE4 & 0.822 & & \\
\cline { 2 - 5 } & SE5 & 0.786 & & \\
\cline { 2 - 5 } & SE6 & 0.797 & & \\
\hline & SE7 & 0.864 & & \\
\hline & SE8 & 0.847 & & \\
\hline Savings & SE9 & 0.675 & & \\
\hline & SE10 & 0.741 & & \\
\hline & SAV1 & 0.847 & & \\
\hline & SAV2 & 0.842 & & \\
\hline & SAV3 & 0.828 & & \\
\hline & SAV4 & 0.865 & & \\
\hline Risk Preference & SAV5 & 0.886 & & \\
\hline & SAV6 & 0.847 & & \\
\hline & RISKP1 & 0.810 & 0.604 & 0.820 \\
\hline
\end{tabular}

Sources: Fieldworks Data Analysis, 2018.

As shown in Table 4, we can see the first variable, self-efficacy, denotes 0.789 , which is higher than 0.674 and 0.484 . The second variable, risk preference, also holds a value of 0.777 , which is higher than other values. Next is savings at 0.853 , which is greater than 0.674 and 0.213 .

Table 4. Discriminant validity index summary for the main three constructs

\begin{tabular}{lccc}
\hline \multicolumn{1}{c}{ Construct } & Financial Self-Efficacy & Risk Preference & Savings \\
\hline Financial Self-Efficacy & $\mathbf{0 . 7 8 9}$ & & \\
\hline Risk Preference & 0.484 & $\mathbf{0 . 7 7 7}$ & \\
\hline Savings & 0.674 & 0.213 & $\mathbf{0 . 8 5 3}$ \\
\hline
\end{tabular}

Sources: Fieldworks Data Analysis, 2018.

\subsection{Relationship between financial efficacy, risk preference, and saving behaviour}

Table 5 compiles the regression weight for the structural model (whole and demographic differentiation). The unstandardised model specification states the goodness of fit indices also have values crucial for testifying the construct validity through fitness indices gained in confirmatory factor analysis (CFA). All categories of fitness indices (absolute fit and incremental fit) achieve their required levels (Byrne, 1998; Fleming et al., 2013; Stacciarini \& Pace, 2017).

Next is the identification of the R-square $\left(\mathrm{R}^{2}\right)$ of the model. For this explanation, we will further examine the standardised model specification where R-Square $\left(\mathrm{R}^{2}\right)$ for savings is 0.66 . This value suggests that the model, which consists of two exogenous variables, financial selfefficacy (SE) and risk preference (RISKP) could predict $66 \%$ of changes in savings (SAV). 
Table 5. Regression weight for structural model (unstandardised)

\begin{tabular}{|c|c|c|c|c|c|c|}
\hline \multicolumn{3}{|c|}{ Regression } & Estimate & S.E. & C.R. & $\mathrm{P}$ \\
\hline \multicolumn{7}{|c|}{ Whole Model } \\
\hline SE & $\begin{array}{l}<---------- \\
\end{array}$ & RISKP & 0.398 & 0.054 & 7.424 & 0.000 \\
\hline SAV & <----------- & SE & 0.859 & 0.057 & 14.985 & 0.000 \\
\hline SAV & <------------ & RISKP & -0.138 & 0.034 & -4.049 & 0.000 \\
\hline \multicolumn{7}{|c|}{ Demographic Differentiation (Urban) } \\
\hline SE & 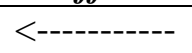 & RISKP & 0.392 & 0.065 & 6.039 & 0.000 \\
\hline SAV & <----------- & SE & 0.851 & 0.068 & 12.470 & 0.000 \\
\hline SAV & <----------- & RISKP & -0.137 & 0.043 & -3.203 & 0.001 \\
\hline \multicolumn{7}{|c|}{ Demographic Differentiation (Rural) } \\
\hline SE & $\begin{array}{ll}<---------- \\
\end{array}$ & RISKP & 0.455 & 0.095 & 4.806 & 0.000 \\
\hline SAV & <----------- & SE & 0.867 & 0.106 & 8.183 & 0.000 \\
\hline SAV & <----------- & RISKP & -0.158 & 0.056 & -2.830 & 0.005 \\
\hline \multicolumn{7}{|c|}{ Demographic Differentiation (Male) } \\
\hline SE & <----------- & RISKP & 0.340 & 0.103 & 3.309 & 0.000 \\
\hline SAV & $<-----------$ & SE & 0.762 & 0.101 & 7.556 & 0.000 \\
\hline SAV & <------------ & RISKP & -0.057 & 0.063 & -0.910 & 0.363 \\
\hline \multicolumn{7}{|c|}{ Demographic Differentiation (Female) } \\
\hline SE & 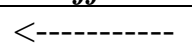 & RISKP & 0.396 & 0.060 & 6.550 & 0.000 \\
\hline SAV & <----------- & SE & 0.920 & 0.070 & 13.070 & 0.000 \\
\hline SAV & <------------ & RISKP & -0.172 & 0.040 & -4.251 & 0.000 \\
\hline
\end{tabular}

Sources: Fieldworks Data Analysis, 2018.

For the whole model, risk positively affects financial self-efficacy at a significance level of $1 \%$, with a regression estimate value of 0.398 , a C.R. of 7.424 , and a p-value of 0.000 . Since the unstandardised coefficient represents the amount of change in the dependent variable per single unit change in the predictor variable, the result suggests for every unit increase in risk, financial self-efficacy is increased by 0.40 . Next, financial self-efficacy has a positive effect on savings at a significance level of $1 \%$, with a regression estimate value of 0.859 , a C.R. of 14.985, and a p-value of 0.000. Every single unit increases in financial self-efficacy and savings increase by 0.86 . Risk shows a negative relationship with savings at a significance level of $1 \%$, with a regression estimate value of -0.138 , a C.R. of -4.049 , and a p-value of 0.000 . This means that saving is decreased by 0.14 for every single unit increase in risk.

The demographic differentiation between the area (urban and rural) and gender (male and female) explained the same relationship between all variables except for the risk towards savings for gender differentiation (male), which pinpointed an insignificant relationship. This suggests that males do not consider any risk when doing the saving. Meanwhile, for demographic differentiation (urban), the significance level between risk and savings is 0.001 and 0.005 for rural. Despite this slight difference, the same relationship is portrayed in comparison to the main model.

The results suggest that risk preference positively affects financial self-efficacy, meaning that the higher the level of risk preference preferred by an individual, the higher their selfefficacy. In other words, individuals who dare to face any uncertainties such as risk have a high efficacy in themselves. This is in line with Bandura (1977), who hypothesises that people bravely take the risk and challenge themselves due to the belief that they can cope with the given situation and maintain a sense of financial self-efficacy. Ogunyemi and Mabekoje (2007) also found that risk preference enhancement combined with financial self-efficacy behaviour could eventually promote personal growth. The finding that risk preference is positively correlated with financial self-efficacy and is statistically significant also supports Densberger (2014). 
The results also show a negative relationship between risk preference and saving, that is, the higher the risk preference owned by an individual, the lower their overall saving. This is supported by Mazzocco (2004) that individuals have low savings because they are willing to bear the risk. This implies that is difficult for the bottom income group to deal with a higher risk for the certain expected return of saving instruments.

The relationship between financial self-efficacy and savings revealed that an individual's high financial self-efficacy could lead to positive saving behaviours. Several researchers have established academic arguments that eventually proved how a sense of financial self-efficacy could end following one's best life decision. Under this study, financial self-efficacy could signal how good a person is doing in their saving or in their investments for their entire lives (Forbes \& Kara, 2010). Asebedo and Seay (2017) strongly suggest that financial self-efficacy beliefs are positively related to saving behaviours.

\section{Conclusion}

The article investigates the empirical support behind the relationships between financial self-efficacy, risk preference, demographic characteristics, and saving decision behaviours. We impose structural equation modelling (SEM) and research design surveys. The unit analysis includes individuals from B40 households. The sampling technique is a multistage sampling cluster systematic random sample. The sample consists of 479 households from three states in Peninsular Malaysia, which was divided into urban and rural areas, as well as males and females.

This study also includes demographic factors that might signal several important facts. For the differentiation of urban and rural area, risk preference did not influence saving; this means that individuals from B40 households are not considering any risks for saving even if they are willing to take other risks in their life because they rarely get a chance to reserve income as savings. For gender differentiation (male and female), the study reveals an insignificant relationship between risk and saving for males. One way to explain this is that men do not think about the risk of doing any saving, whereas women take significant risks, which is one of the reasons why they are able to save.

The results' implication policy is that financial self-efficacy, risk preference, and demographic characteristics are clearly essential for determining savings decision behaviours. Therefore, the government should consider these variables in when developing government policies and firms should also be given information regarding the preference of an individual in terms of their saving decision behaviours.

\section{Acknowledgement}

This study was funded by the Fundamental Research Grant Scheme (FRGS) Under Reference Code; FRGS/1/2016/SSO8/UMT/02/6. We would like to thank the Ministry of Education of Malaysia for financial support. 


\section{References}

Asebedo, S. D., \& Seay, M. C. (2018). Financial self-efficacy and the saving behaviour of older pre-retirees. Journal of Financial Counselling and Planning, 29(2), 357-368. http://dx.doi.org/10.1891/1052-3073.29.2.357

Asebedo, S. D., Wilmarth M. J., Seay, M. C., Archuleta, K., Brase, G. L. \& MacDonald, M. (2019). Personality and Saving Behavior among Older Adults. The Journal of Consumer Affair, Vol 53(2), 488-519. https://doi.org/10.1111/joca.12199

Bandura, A. (1977). Self-efficacy: Toward a Unified Theory of Behavioural Change. Psychological Review, 84, 191-215.

Bandura, A., \& Wood, R. (1989). The effect of perceived controllability and performance standards on self-regulation of complex decision making. Journal of Personality and Social Psychology, 56 (5), 805-814.

Bandura, A. (1994). Regulative function of perceived self-efficacy. In M. G. Rumsey, C. B. Walker, \& J. H. Harris (Eds.), Personal selection and classification (pp. 261-271). Hillsdale, NJ: Erlbaum

Bosworth, B., Burtless, G., \& Sabel- Haus, J. (1991). The Decline in Saving: Evidence from Household Surveys. Brookings Pap. Econ. Act., 1, 183-241.

Brown, S., Garino, G., Simmons, P., \& Taylor, K. (2008). Debt and Risk Preference: A Household Level Analysis.

Byrne, B. M. (2010). Structural Equation Modelling with AMOS (2nd Ed.). New York: Routledge.

Callander, E. J., \& Schofield, D. J. (2016). The Impact of Poverty on Self-Efficacy: An Australian Longitudinal Study. Occupational Medicine, 66(4), 320-325. https://doi.org/10.1093/occmed/kqw017

Campbell, J. Y. (2006). Household Finance. The Journal of Finance, LXI(4), 1553-1604. https://doi.org/10.1111/j.1540-6261.2006.00883.x

Chatterjee, S., Finke, M. \& Harness, N. (2011). The Impact of Self-Efficacy on Wealth Accumulation and Portfolio Choice. Applied Economics Letters, 18. 627-631. https://doi.org/10.1080/13504851003761830.

Cobb-Clark, D. A., Kassenboehmer, S. C., \& Sinning, M. G. (2016). Locus of Control and Savings. Journal of Banking \& Finance, Vol. 73, 113-130.

Densberger, K. (2014). The Self-Efficacy and Risk-Propensity of Entrepreneurs. Journal of Enterprising Culture, 22(4), 437-462. https://doi.org/10.1142/S0218495814500186

Farrell, E., Fry, Tim R.L., \& Risse, L. (2015). The significance of financial self-efficacy in explaining women's personal finance Behaviour. Journal of Economic Psychology http://dx.doi.org/10.1016/j.joep.

Fisher, P. J. (2010). Gender differences in personal saving behaviours. Journal of Financial Counselling and Planning, 21(1), 14-24.

Fleming, M., House, S., Hanson, VS., Yu, L., Garbutt, J., McGee, R., Kroenke, K., Abedin, Z., \& Rubio, D. (2013). The Mentoring Competency Assessment: Validation of a New Instrument to Evaluate Skills of Research Mentors. Acad Med., 88(7), 1002-1008. https://doi:10.1097/ACM.0b013e318295e298

Forbes, J., \& Kara, S. M. (2010). Confidence mediates how investment knowledge influences investing self-efficacy. Journal of Economic Psychology, 31, 435-443.

Fornell, C., \& Larcker, D. F. (1981). Evaluating Structural Equation Models with Unobservable Variables and Measurement Error. Journal of Marketing Research, Vol. 18(1), 39-50.

Hopkins, B. E., \& Todorova, Z. (2014). Gender Dimensions of the U.S. Consumer Borrowing Expansion. Journal of Economic Issues, 48(2), 501-506. 
Hussain, M., Anwar, S., \& Huang, S. (2016). Socioeconomic and Demographic Factors Affecting Labor Force Participation in Pakistan. Journal of Sustainable Development, 9(4), 70-79. http://dx.doi.org/10.5539/jsd.v9n4p70

Hufner, F. and I. Koske (2010). Explaining Household Saving Rates in G7 Countries: Implications for Germany. OECD Economics Department Working Papers, No. 754, OECD Publishing, Paris, https://doi.org/10.1787/5kmjv81n9phc-en.

Kickul, J., Wilson, F., Marlino, D., \& Barbosa, S.D. (2008). Are Mis-Alignments of Perceptions and Self-Efficacy, Causing Gender Gaps in Entrepreneurial Intention among Our Nation's Teens? J. Small Bus. Enterp. Dev., 5 (2), 321-335.

Lian, C. and Ma, Y. (2018). Low-Interest Rates and Investor Behaviour: A Behavioural Perspective. 62th Economic Conference at the Federal Reserve Bank of Boston. 1-46.

Lown, J. M. (2011). Development and validation of a financial self-efficacy scale. Journal of Financial Counseling and Planning, 22(2), 54-63.

Lown, J. M. (2015). Development and Validation of A Financial Self-Efficacy Scale. Journal of Family and Economic Issues, 36(4), 491-502.

Maciejewski, P.K., Prigerson, H.G., \& Mazure, C.M. (2000). Self-efficacy as a mediator between stressful life events and depressive symptoms. Differences based on the history of prior depression. British Journal of Psychiatry, 176. 373-378.

Magendans, J., Gutteling, J., \& Zebel, S. (2016). Psychological Determinants of Financial Buffer Saving: The Influence of Financial Risk Tolerance and Regulatory Focus. Journal of Risk Research. http://dx.doi.org/10.1080/13669877.2016.114749.

Marlatt, G. A., \& Donovan, D. M. (Eds.) (2005). Relapse prevention: Maintenance strategies in the treatment of addictive behaviors (2nd ed.). The Guilford Press.

Mazzocco, M. (2004). Saving, Risk Sharing and Preferences for Risk. Working Paper, University of Wisconsin.

Ogunyemi, A. \& Mabekoje, S. (2007). Self-efficacy, risk-taking behavior and mental health as predictors of personal growth initiative among university undergraduates. Electronic Journal of Research in Educational Psychology, 5, 349-362.

Prati, G., Pietrantoni, L., Cicognani, E. (2009). Self-Efficacy Moderates the Relationship between Stress Appraisal and Quality of Life among Rescue Workers. Anxiety, Stress, and Coping, 23(4), 463-70. https://doi.org/10.1080/10615800903431699

Tokunaga, H. (1993). The Use and Abuse of Consumer Credit: Application of Psychological Theory and Research. Journal of Economic Psychology, 14. 285-316. https://doi.org/10.1016/0167-4870(93)90004-5.

Trent, K., \& South, S. (1992). Sociodemographic status, parental background, childhood family structure, and attitudes toward family formation. Journal of Marriage and the Family, 54, 427-439.

Ramiah, V., Xu, X., \& Moosa, I.. (2015). Neoclassical Finance, Behavioral finance and Noise Traders: A review and assessment of the literature. International Review of Financial Analysis, 41(C), 89-100.

Rimal, Arbindra \& Moon, Wanki \& Balasubramanian, Siva K. \& Miljkovic, Dragan, 2011. Self Efficacy as a Mediator of the Relationship between Dietary Knowledge and Behavior. Journal of Food Distribution Research, Food Distribution Research Society, 42(3), 1-14.

Rothwell, D.W., Khan, M.N \& Chetney, K. (2016) Building Financial Knowledge Is Not Enough: Financial Self-Efficacy as a Mediator in the Financial Capability of Low-Income Families. Journal of Community Practice, 4(24), 368-388. 
Schwarzer, R., \& Jerusalem, M. (1995). Generalised Self-Efficacy Scale. In J. Weinman, S. Wright, \& M. Johnston, Measures in Health Psychology: A User's Portfolio. Causal and Control Beliefs (pp. 35-37). Windsor, UK: Nfer-Nelson.

Scholz, J.K., Seshadri, A., Khitatrakum, S. (2006). Are Americans Saving "Optimally" for Retirement? Journal of Political Economy, 114(4), 607-643.

Stacciarini. T.S.G. \& Pace A.E. (2017). Confirmatory factor analysis of the Appraisal of SelfCare Agency Scale-Revised. Rev. Latino-Am. Enfermagem, 25:e2856. http://dx.doi.org/10.1590/1518-8345.1378.2856.

Willis, L. E. (2008). Against financial-Literacy education. Iowa Law Review, 94, 197-285. 


\section{APPENDICES}

\section{A. Original items adapted from GSES}

Please respond to the following statements using these response categories:

$1=$ totally disagree $2=$ disagree $3=$ undecided $4=$ agree $5=$ totally agree

(Items 4, 7 and 9 are reverse-scored)

\begin{tabular}{llr}
\hline Item & \multicolumn{1}{c}{ Indicator } & $\begin{array}{r}\text { Factor } \\
\text { Loading }\end{array}$ \\
\hline 1 & I can always manage to solve difficult problems if I try hard enough & $\mathbf{0 . 4 8 0}$ \\
\hline 2 & It is hard to stick to my spending plan when unexpected expenses arise & 0.616 \\
\hline 3 & It is challenging to make progress toward my financial goals & 0.658 \\
\hline 4 & When unexpected expenses occur, I usually have to use credit & 0.682 \\
\hline 5 & I am confident that I could deal efficiently with unexpected events & 0.744 \\
\hline 6 & When faced with a financial challenge, I have a hard time figuring out a solution & 0.714 \\
\hline 7 & I lack confidence in my ability to manage my finances & 0.773 \\
\hline 8 & I can solve most problems if I invest the necessary effort & 0.798 \\
\hline 9 & I worry about running out of money in retirement & 0.621 \\
\hline 10 & $\begin{array}{l}\text { I can remain calm when facing difficulties because I can rely on my coping } \\
\text { abilities. }\end{array}$ & 0.696 \\
\hline
\end{tabular}

\section{B. Individual risk preference}

\begin{tabular}{llr}
\hline Item & \multicolumn{1}{c}{ Indicator } & $\begin{array}{r}\text { Factor } \\
\text { Loading }\end{array}$ \\
\hline 1 & $\begin{array}{l}\text { Do you dare to take any risk that relates to financial uncertainty } \\
\text { (Daily Risk) }\end{array}$ & 0.783 \\
\hline 2 & $\begin{array}{l}\text { Do you dare to take any risk that relates to financial uncertainty } \\
\text { (Small Risk) }\end{array}$ & 0.861 \\
\hline 3 & $\begin{array}{l}\text { Do you dare to take any risk that relates to financial uncertainty } \\
\text { (Huge Risk) }\end{array}$ & 0.842 \\
\hline
\end{tabular}

\section{Savings Behaviour}

\begin{tabular}{llc}
\hline Item & \multicolumn{1}{c}{ Indicator } & $\begin{array}{c}\text { Factor } \\
\text { Loading }\end{array}$ \\
\hline 1 & $\begin{array}{l}\text { I choose short term savings (monthly savings, fixed deposits, monthly salary } \\
\text { deductions) / long term savings (gold, unit trust funds (ASB), premium } \\
\text { certificate saving (SSP)) }\end{array}$ & 0.594 \\
\hline 2 & $\begin{array}{l}\text { I save in the form of savings protection (life insurance, education, health care } \\
\text { and so on) }\end{array}$ & 0.670 \\
\hline 3 & Monthly savings to make I am not disciplined because it is not periodic & 0.689 \\
\hline 4 & I set aside savings for emergencies & 0.699 \\
\hline 5 & I make savings on my own (not the bank) & 0.698 \\
\hline 6 & I will focus on short/long term savings over the next 5 years. & 0.685 \\
\hline
\end{tabular}

